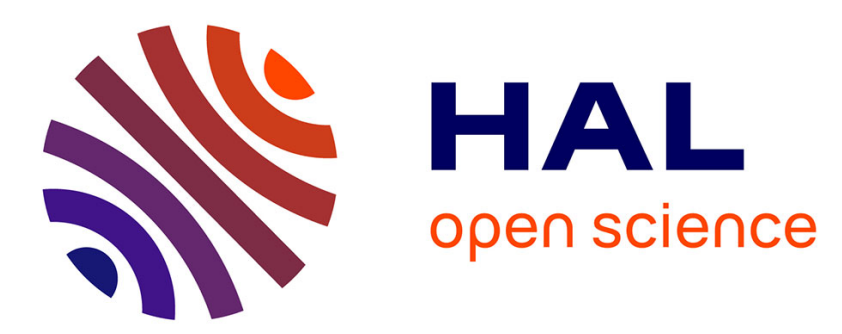

\title{
Structural pattern of the Saïss basin and Tabular Middle Atlas in northern Morocco: hydrological implications
}

Olivier Dauteuil, Frédérique Moreau, Khaoula Qarqori

\section{To cite this version:}

Olivier Dauteuil, Frédérique Moreau, Khaoula Qarqori. Structural pattern of the Saïss basin and Tabular Middle Atlas in northern Morocco: hydrological implications. Journal of African Earth Sciences, 2016, 119, pp.150-159. 10.1016/j.jafrearsci.2016.04.001 . insu-01300836

\section{HAL Id: insu-01300836 https://hal-insu.archives-ouvertes.fr/insu-01300836}

Submitted on 11 Apr 2016

HAL is a multi-disciplinary open access archive for the deposit and dissemination of scientific research documents, whether they are published or not. The documents may come from teaching and research institutions in France or abroad, or from public or private research centers.
L'archive ouverte pluridisciplinaire HAL, est destinée au dépôt et à la diffusion de documents scientifiques de niveau recherche, publiés ou non, émanant des établissements d'enseignement et de recherche français ou étrangers, des laboratoires publics ou privés. 


\section{Accepted Manuscript}

Structural pattern of the Saïss basin and Tabular Middle Atlas in northern Morocco: hydrological implications

O. Dauteuil, F. Moreau, K. Qarqori

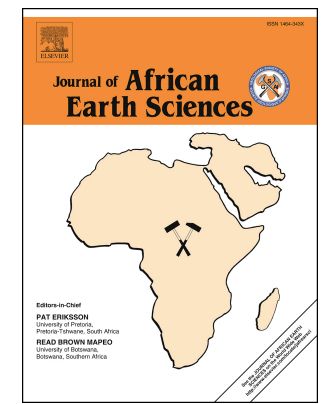

PII: S1464-343X(16)30108-X

DOI: $\quad$ 10.1016/j.jafrearsci.2016.04.001

Reference: $\quad$ AES 2537

To appear in: Journal of African Earth Sciences

Received Date: 27 July 2015

Revised Date: 31 March 2016

Accepted Date: 1 April 2016

Please cite this article as: Dauteuil, O., Moreau, F., Qarqori, K., Structural pattern of the Saïss basin and Tabular Middle Atlas in northern Morocco: hydrological implications, Journal of African Earth Sciences (2016), doi: 10.1016/j.jafrearsci.2016.04.001.

This is a PDF file of an unedited manuscript that has been accepted for publication. As a service to our customers we are providing this early version of the manuscript. The manuscript will undergo copyediting, typesetting, and review of the resulting proof before it is published in its final form. Please note that during the production process errors may be discovered which could affect the content, and all legal disclaimers that apply to the journal pertain. 

northern Morocco: hydrological implications

2) Earth Sciences Department, Faculty of Sciences, Moulay Ismail University, 11201 Zitoune 50000, Meknes,

\section{Abstract}

The plain of Saïss is a fertile area of great agricultural production with major economic interests. Therefore, the improved knowledge about the water supply is imperative within a context of recurrent droughts and overexploitation of the groundwater. This plain is located in the Meknes-Fes basin and between two deformed domains: the Rif and Middle Atlas. The aquifers are fed by water coming from the Tabular Middle Atlas, for which the pathways are poorly constrained. This study provides new data to determine the water pathways based on a structural map produced from a novel analysis of SPOT images and a digital elevation model. This structural map reveals two fracture sets trending NE-SW and NW-SE. The first set is well known and corresponds to a main trend that controlled the tectonic and stratigraphic evolution of the study area. On the other hand, the NW-SE set was poorly described until now: it is both diffuse and widespread on the Tabular Middle Atlas. A comparison between the regional water flow trend, drainage pattern and structural map shows that the NW-SE fractures control the water flow from the Tabular Middle Atlas to the Saïss plain. A hydrological model is discussed where the water flow is confined onto Liassic carbonates and driven by NW-SE fractures. This study explains how a detailed structural mapping shows hydrology constraints.

Keywords: structural map, SPOT images, DEM, water circulation

\section{1- INTRODUCTION}

The Atlas chains developed from the inversion of the Jurassic rift or transtensional basins as a consequence of continental convergence between Africa and Europe during the Cenozoic. The mountain ranges are associated with high seismic activity revealing intense deformation and defining several domains with their 
own history and structures (Chalouan et al., 2014). These domains are separated into less-deformed intraorogenic basins (Bargach et al., 2004; Barbero et al., 2011) (Fig. 1). The Saïss plain, associated with the Meknes-Fes basin, is one of these intraorogenic basins that separates the Rif orogen from the Middle Atlas. Terrigenous sediments, with ages ranging from the Miocene to the Pleistocene, fill this basin, which was isolated during the Miocene. The southern and northern limits correspond to thrusts that were active during the Late Miocene (Piqué et al., 2002; Frizon de Lamotte et al., 2011), and the Alpine convergence is usually assumed to have only slightly affected the basin. This unusual behaviour should be investigated to understand The regional structural analysis provided by SPOT images and digital elevation model (DEM) can be used to complete the existing data set.

The Meknes-Fes basin is a wide plain of major economic interest because of intense agriculture and the location of great cultural and touristic sites in the imperial cities of Fes and Meknes. All these human activities require large water resources that come from two aquifers: one that is deep in the Liassic units and a second shallow one in the Plio-Pleistocene deposits. The poor remediation of water rejected into the rivers (Perrin et al., 2014) imposes the use of water in the deep aquifer. The Tabular Middle Atlas, with a higher topography and higher rainfall, mainly supplies the two aquifers. Water flow connections between these two domains remain poorly constrained and must be investigated to improve the management of water resources in this region. The water pathways are controlled by several parameters including the rock porosity, lithology, fracture pattern and structure layering. However the investigation to determine these pathways is complex and requires combined approaches. Thus, we propose to use surface structural mapping based on by SPOT images and DEM interpretation, combined with drainage pattern and hydrological information, to determine the potential water pathways.

\section{2- GEOLOGICAL AND HYDROLOGICAL SETTINGS}

\section{1- Geological framework}

The Middle Atlas and Rif mountains represent two major structural domains in northern Morocco that are separated by the Fes-Meknes basin (Fig. 1). The Middle Atlas shows two different geomorphic areas (Barcos et al., 2014): a northwest domain with tabular relief (the Tabular Middle Atlas or TMA), and a northeast-southwest domain with a mountainous relief linked to the High Atlas. The TMA represents a key area for the water supply of the Saïss plain associated with the Fes-Meknes basin. The TMA is a large karstic reservoir from which water flows out to the plain. However, the water circulation paths are not precisely constrained, and this is one of the aims of this study.

The TMA has a roughly flat topography at an elevation of $1100 \mathrm{~m}$ on the western side while the eastern side is higher $(1400 \mathrm{~m})$ and more incised. NE-SW linear and long valleys and NW-SE short valleys shaped the topography (Fig. 2). The western flat part is sparsely covered by vegetation while the eastern mountainous part is largely covered by vegetation, mainly forests. The southern border of the TMA corresponds to erosion scarp that forms a window on the basement of the TMA. To the north of the TMA, the Saïs basin forms a plain with a total surface area of $2,100 \mathrm{~km}^{2}$ and northward regional tilting: $850 \mathrm{~m}$ in the south and $525 \mathrm{~m}$ in the north, i.e. an approximate regional slope of $1 \%$. To the NE of the plain, the Fes sub-basin has a flat morphology that is $130 \mathrm{~m}$ lower than the western sub-basin. This plain is deeply incised on the borders of the western and northern 
sides, while there are very few rivers in the middle and southern parts. The main streams trend NE-SW and EW (Fig. 2). The Saïss plain and the TMA have the same geological evolution until the Cenozoic. Triassic evaporites unconformably cover the Palaeozoic basement that was deformed during the Hercynian orogeny. During the Liassic opening of the Tethysian Ocean, carbonates (limestones and dolomites) with significant thicknesses were deposited. In the study area, this extension trends NW-SE, which generated NE-SW blocs controlling the deposit centres. Then, a large depositional gap occurred until the Neogene and the evolution of the TMA and Saïss basin diverged (Ennadifi, 1975; Arboleya et al., 2004; Amraoui, 2005; Qarqori et al., 2012). During the Late Miocene, the Fes-Meknes basin in the north became a deep marine trough trending NE-SW and filled with a thick sequence of shales with turbidites (Charroud et al., 2007; Bachiri Taoufiq et al., 2008). Then, a main environmental change occurred during the Plio-Quaternary generating the depositional context, evolving from lacustrine to fluvial with lacustrine limestone, conglomerate and sandstone deposits. This change resulted in a general uplift of the whole study area. Also, the deposit of a significant amount of travertine on the northern edge of the TMA should be noted (Chamayou et al., 1975). Since the late Miocene, the TMA became a horst that was emerged until now. The Liassic carbonates were largely weathered, generating a large karstic plateau with the emergences of springs at the junction with the Saïss basin. During the Pleistocene, the plateau was locally covered by alkaline basalt lava flows coming from the Outgui volcano and flowing to the Saïss plain into the pre-existing valley. A recent GPS study (Chalouan et al., 2014) reveals that the contact between the two domains is affected by a slow divergence associated with normal faults with a dextral slip component, trending NE-SW.

The TMA displays two fault sets: one trending NE-SW corresponding to the main faulted zones that are well known in the Rif domain and in the Middle Atlas (Morel, 1989, Ait Brahim and Chotin, 1989; Aït Brahim et al., 2002; Frizon de Lamotte et al., 2009; Vergés and Fernandez, 2012) and a second one oriented NW-SE that has been less described (Amraoui, 2005). This latter trend is locally described in the Middle Atlas, Rif ranges (Ait Brahim et al., 2002) and Alboran basin (Vergés and Fernandez, 2012). The main NE-SW faulted corridors located on the TMA did not affect these recent basaltic flows. The structural framework of the Saïss basin is poorly defined because of the vegetation cover. Morel (1989), Ait Brahim and Chotin (1989), Amraoui (2005), Ait Brahim et al. (2002), and Frizon de Lamotte et al. (2009) described a set of NE-SW features for which the locations and types have been debated: normal faults, strike-slip faults or flexures.

\section{2- Hydrological context}

The water supply for human activities in the Saïss plain comes from three locations: a shallow aquifer located in the Plio-Pleistocene sediments, a deep aquifer located within the Liassic dolomites and limestone, and springs located on the boundary between the TMA and the plain. Although rainfall mainly feeds the shallow aquifer, the deep aquifer is filled both by infiltration coming from the surface water and by deep circulations of water coming from the TMA (Amraoui, 2005; Belhassan, 2011). The recharge of aquifer located inside the Saïss basin is largely controlled by precipitation occurring in the TMA (Amraoui, 2005; Belhassan, 2011). The high elevations of the TMA favour rainfall that penetrates inside the Liassic dolomite karst. The rainfall can reach $1000 \mathrm{~mm} / \mathrm{yr}$ close to Ifrane, which is twice as high as in the plain (550 mm at Meknes, for instance). In the Atlas plateau, the surface run-off is restricted because of the presence of fractures and dissolution sinks forming the karst system at depth. The water primarily flows northward and comes out of the base of the TMA through 
several springs mainly located between the area of Ribaa and Bittit (Bentayeb and Leclerc 1977). Essahlaoui et al. (2001) and Qarqori et al. (2012) used a geo-electrical tomography survey to explore the structural pattern at the junction between the TMS and the plain, close to the Bittit spring (Fig. 2). These geophysical surveys established a structural framework for the deep aquifer located in the Liassic formation. Qarqori et al. (2012) pointed out northward to north-westward water circulations in the Bittit spring through sub-vertical fractures and horizontal joints. However the fracture pattern driving the water flow has not been described in classical structural work. We propose to carry out a complete structural investigation to better constrain the water circulation filling the aquifers.

\section{3- METHODOLOGY AND DATA}

The first step of this study is to create the most comprehensive map possible of the structures affecting the area. Then the map is compared to local hydrogeological data to propose which deep and connected features are potential water drains. We focus more specifically on regional features, which connect the TMA to the Saïss plain. In the studied region, remote data such as satellite images or DEM provide widespread coverage that can be used to integrate the whole aquifer system from the filling area to the aquifer. The proposed methodology is based on a coupling between the analysis of the satellite imagery (SPOT images) and DEM data in order to extract pertinent lineations that may be related to the surface geology and not to human activities. The DEM was processed using the LandSerf software (version 2.3.1) developed by J. Wood. This kind of structural map is classically used in addition to field observations to infer the deformation history of a region. We improve the use of this map by comparing it to pre-existing hydrological work. Different processing techniques for the satellite images that are particularly adapted to extract hydrogeological information are proposed. These maps and the hydrological data were integrated into a GIS (QuantumGIS) and were interpreted by coupling the different images produced.

\section{1- Satellite images}

Satellite images are powerful data to map geological objects over large areas. However, the vegetation masks the structural pattern in several places. In order to cover the entire Saïss plain region, seven SPOT images (Figs. 3 and 4) were used with a pixel size ranging from $2.5 \mathrm{~m}$ to $10 \mathrm{~m}$ and with different spectral modes (see the more detailed technical description in Table 1 and locations in Figure 3). We restricted the image processing to classical methods that can be used to extract structures: dynamic stretching, contrast enhancements (Fig. 4) and edge detections. We focused on methods extracting linear objects that can be interpreted as structural features (fractures, faults, schistosity and stratas). The edge extraction was done with Sobel filters composed of four

142 diagonal matrixes of $5 \times 5$ pixels corresponding to the N-S, E-W, NE-SW and NE-SW directions, respectively

143 (Fig. 5). These different calculations reveal several lineaments and features that are more visible on the TMA 144 and more discrete on the plain of Saïss. These differences can be attributed to the vegetation, the development of 145 which is largely controlled by human activities in the plain compared to the TMA, to the lithology of the 146 basement (carbonate versus terrigenous sediment, respectively) and to the deformation history, which is different 147 in the two domains. By combining the results provided by SPOT images with DEM interpretations, the differences due to human activities and to vegetation can be filtered out. 


\section{2- Digital topography}

The relief provides information about geology because it is sensitive to the structure (fault, strata orientation) and to differential erosion induced by the lithological contrast. The digital topography can be processed to extract structural data (Dauteuil, 1995). We used SRTM DEM with a pixel size of $30 \mathrm{~m}$ to analyse the pattern of the topography and to extract features that will be compared to those coming from the analysis of the SPOT images (Fig. 3). The plain of Saïss displays a relatively flat morphology, and consequently we used geomorphic indexes to extract the structural and geological features that were subsequently correlated to the features mapped from the SPOT images. To extract the structural features, we used both the usual processing techniques, such as shaded images with different light directions (Fig. 6), and slope calculations (Fig. 7) (Dauteuil, 1995). We analysed the average slopes at different scales by estimating the azimuth and dip of a mean plane supported by points belonging to a moving window. The best-adjusted plane was calculated by a least squares fitting. Two windows were calculated: a small one $(2.5 \times 2.5 \mathrm{~km})$ for the smaller scale and a large one $(7.5 \times 7.5 \mathrm{~km})$ for the larger scale. The result of this slope analysis will be compared to the drainage pattern because of the strong a priori correlation between the water flows and slope direction. Finally, the feature network including the channel, isolated peaks and topographic ridges was extracted (Fig. 8) via processing with the LandSerf GIS software (Fisher et al., 2004; Wood, 2013).

\section{4- RESULTS}

\section{1- Interpretation of the SPOT images}

The SPOT images show large differences in the radiometric pattern between the TMA, Palaeozoic basement and plain. The Palaeozoic basement shows well-defined ridges trending at N030 ${ }^{\circ}$ with sparse vegetation (shown in red in the pseudo-colour image - Fig. 4). The TMA displays various radiometric types: the dark red colour corresponds to forests; the medium grey colour indicates volcanic flows and the heterogeneous grey-to-red areas delineate a mixture between grass and rock. Conversely to the basement, no main organized features are noticeable on the TMA, except in the NE part where wide and narrow linear valleys trend at $\mathrm{N} 030^{\circ}$. Close to the border with the plain, some narrow and short valleys are oriented approximately N $300^{\circ}$. In the Saïss plain, the radiometric pattern is very heterogeneous with several small patches of various colours (light grey, dark grey, white and red) with regular shapes. This pattern is driven by human activities (crop field, roads, farms, etc.). There is no main organization or linear feature, except for a tiny NW-SE-oriented trend associated with farming and small rivers, especially in the north of the plain, around the town of Meknes.

The results of the contour detection techniques confirm and highlight the previously described structural characteristics. Figure 5 provides representative zooms of two different Sobel processing operations with the dominant features. The direction of the lineaments in the TMA is relatively homogeneous compared to the wellshaped basement and fined-shaped plain. NNE-SSW features are well extracted on the basement in the south and in the TMA, while they are scarcer in the plain. A NW-SE trend dominates the structural pattern of the plain: the

183 features are thin and close to each other. In addition, some NE-SW linear features are localized in corridors that have the same trend (upper image in Fig. 5). A large number of extracted lineaments are associated with farm fields. The MNT analysis must be used together with this SPOT contour image to identify the anthropogenic 
lineaments. The combined analysis of remote images and DEM allow geological lineaments to extract. This

NW-SE direction is scarcely reported in field studies while it appears clearly on satellite images.

\section{$\underline{4.2-\text { Topography analysis }}$}

The topography that is less sensitive to the vegetation may constitute powerful complementary data to extract tectonic features. The shaded images (Fig. 6) and slope calculations at different scales (Figs. 7a and 7b) display different relief patterns in the Palaeozoic basement, TMA and Saïs plain. Regardless of the scale, the Saïss plain has the gentlest slopes with highest values organized into narrow bands trending NW-SE and WNWESE, corresponding to permanent or semi-permanent rivers and to local anomalies on the topographic surface. As expected, the rugged relief of the TMA shows the highest values coming from elevated relief relative to the surrounding areas and the tectonics, seen both on the slope and in the shaded images. The slopes are mainly organized into NE-SW bands, except to the NE of El Hajeb where the TMA border displays NW-SE short valleys. The Palaeozoic basement clearly shows NE-SW reliefs with high slopes separated by narrow flat plains. At local scales, the slopes ( $2.5 \times 2.5 \mathrm{~km}$ window) do not display well-organized azimuth trends: the slopes plunge roughly perpendicular to the relief with a maximum toward the $\mathrm{N}$ to NNE. At a more regional scale $(7.5 \times 7.5$ $\mathrm{km}$ window), the slopes gradually plunge northward in the south to westward in the plain with a maximum trending NW. The Rif area shows slopes plunging NE to ENE. We compare the slope plunge to the river drainage direction in Figure 7: the river streams mainly trend N-S and NW-SE. These trends are slightly different by $10^{\circ}$ from the maximum slope plunge, indicating that the regional slope partially drives the river trends and that another process should be inferred as a consequence (Fig. 7).

The geomorphic structure network (Fig. 8) confirms the difference in morphology patterns between the TMA, plain and Rif domain. The structure network is denser in the TMA and Palaeozoic basement than in the Saïss plain. In the plain, ridges are almost absent near the TMA while they are well developed in the NW part around the town of Meknes where they separate into channels, i.e. drains. The channels in the plain display a dendritic pattern close to the TMA border and long streams in the middle of the plain. Topographic ridges are absent on the southern border of the plain. This change in drainage pattern corresponds to a change in drainage direction from NNW-SSE to NW-SE. These changes in the drainage pattern characteristics and the limit of the topographic ridges correspond to a NE-SW trending band (Fig. 8) that separates the Saïss plain into two domains: the NW part and SE part. On the border with the TMA, a lot of drains are associated with springs located on the mid-slope of the relief between the two domains. In the TMA, the drainage pattern corresponds to an irregular dendritic pattern with well-nested topographic ridges and channels. The channels and ridges have short and wavy segments. The main and longer channels trend NE-SW.

\section{5- Interpretations}

\section{1- Structural pattern}

The combined interpretation of the SPOT images and topography allows us to produce a structural map to establish the tectonic relationships between the TMA and plain (Fig. 9). The analysis also reveals that the structural pattern of the study area is driven by two perpendicular sets of lineaments: NE-SW and NW-SE. 
The NE-SW structures dominate the shape of the TMA: they correspond to well-known features in the Atlas domain and Rif domain (Morel, 1989, Ait Brahim and Chotin, 1989; Ait Brahim et al., 2002; Frizon de Lamotte et al., 2009; Vergés and Fernandez, 2012). They affect the entire area, and some corridors display more fractures generating long valleys with a flat bottom. The displacements along these features cannot be determined from this analysis because of the lack of well-defined markers. However, the geomorphic shape of these features indicates both vertical and horizontal components in agreement with previous studies (Aït Brahim et al., 2002; Arboleya et al., 2004; Bargach et al., 2004; Frizon de Lamotte et al., 2009). This work points out that NE-SW features localized into restricted corridors affected the plain of Saïss (Fig. 9). These latter corridors were previously described as bends by Fassi (1999) and Amaraoui (2005): the Toudal bend, Koudiart Zouarl bend, Souk Jemad El Gour bend and Boufekrane - Haj Kaddour bend. These features drive the orientation and type of drainage network, and correspond to discontinuous slope breaks. This direction was active since the Triassic and controlled the Triassic to middle Jurassic deposits (Piqué et al., 2002; Frizon de Lamotte, 2009) and the Miocene filling of the Saïss basin (Essahlaoui et al., 2000; 2001; Amaraoui, 2005). This structural set is partially imaged at depth with seismic profiles (Zizi, 2002) displaying a fault inside the Cenozoic deposits that is in agreement with stratigraphic correlations from boreholes (Charroud et al., 2007). Electrical surveys (Essalahoui et al., 2000) highlight a NW-SE structural trend that is well-organized at depth (4 km).

The NW-SE structural set was found in the whole study area with various patterns. In the TMA, it is diffuse and associated with narrow V-shape valleys. In some places, these features offset NE-SW structures indicating a strike-slip component. This trend is less described than the NE-SW features. Ait Brahim and Chotin (1989) and Vergés and Fernandez (2012) suggest strike-slip fault zones accommodating deformation transfer. The plain of Saïss is affected by tiny and diffuse NW-SE fractures. This deformation is widespread over the plain and corresponds to a set of short segments compared to the NE-SW band, which has longer and localized segments. The fractures of the NW-SE band control some permanent and semi-permanent rivers to the south of the town of Meknes. Close to the TMA, this set is not systematically associated with drainage features. In the depression of Fes, deformation appears to be less intense and less widespread. The associated features correspond to changes in the slope and with small rivers. The structural set was previously poorly described because it corresponds to a pattern of widespread fracturing that can be observed at the outcrop scale (Qarqori et al., 2011). The geophysical surveys did not describe this in depth, probably because it corresponds to diffuse features that are difficult to image with classical geophysical methods. However, an electrical survey (Essalahoui et al., 2002; Essahlaoui and El Ouali, 2003) displays anomalies trending NW-SE at 100 and $1000 \mathrm{~m}$ in the western part of the Saïss basin, fitting with this structural trend. Thus, the NW-SE features detected at the surface are present at depth.

\section{2- Deformation timing}

A deformation timing can be advanced from geological arguments and from the new observations coming from this study. First of all, the two sets of structures did not affect the volcanic flows dated as late Quaternary or the Pleistocene sediments; however, they do affect the Pliocene deposits, revealing that they occurred at the end of the Pliocene. The relative chronology between the two fracture sets can be determined 
locally where the NW-SE fractures offset the NE-SW features. At the regional scale, the contact between the TMA and the Saïss basin trends NE-SW, and it is often locally offset by NW-SE faults. Therefore, the NW-SE features were generated after the NE-SW features. These faulted zones have been previously described (Ait Brahim et al., 2002; Piqué et al., 2002; Arboleya et al., 2004) and seem to control, at least partially, the depositional centres and deformation in these areas since the Late Triassic (Jabour et al., 2004; Frizon de Lamotte et al., 2009). They were interpreted as resulting from the reactivation of the Liassic fault systems during the different Mio-Pleistocene events. During the Late Miocene, this fault set played a major role in the generation of horsts and grabens. The larger horst is the TMA, which was isolated from the Saiiss basin by a major normal fault (Ait Brahim et al., 2002). The elevated topography of the TMA was acquired at this time because no marine shales were described on this plateau. Inside the basin, the normal NE-SW faults confined several depositional centres with variable thicknesses. The deformation period corresponds to a NW-SE stretching. During the Pliocene, they were reactivated as steep thrusts probably with a strike-slip component (Bargach, et al., 2004; Charroud et al., 2007). This change in fault kinematics is consecutive to a rotation of the regional stresses. This deformation is not still very active because many of the features were sealed by lava flows and travertines during the Middle to Late Pleistocene.

The diffuse deformation generated late NW-SE features. This deformation is recent and happened during a short event. It partially controlled the erosion of the TMA by generating short valleys and the new setting of the rivers in the basin, especially around the town of Meknes. The deformation is associated with a NE-SW stretching and is compatible with the NW-SE to N-S trends of compression described by Bargach et al. (2004). The genesis of these feature sets favoured the location of a new drainage pattern, which was formed during a base level fall. This change in drainage reorganization corresponds to the palaeogeographic drying of the Pleistocene lake after a fast withdrawal compatible with the base level fall.

\section{3- Hydrogeological outcomes}

This work determined the fracturing pattern of the study area in order to propose which structure set is the most efficient to drain water from the TMA to the plain. We will investigate the possible structural pathways: the two fracture sets described before, and the stratigraphic layering, which corresponds to horizontal or sub-horizontal drains located both in the TMA and in the Fes-Meknes basin (Fig. 1). The most significant difficulty is to extrapolate 2D surface data to the 3D connected deep network. Due to the lack of geophysical surveys at the regional scale, we used indirect observations.

The first-order field evidence of water circulation coming from the TMA is the presence of many springs located at the junction between the TMA and the plain (Fig. 10), close to the unconformity between the dolomitic karst and the Palaeozoic basement (Zarhloule, et al. 2001; Amraoui 2005). They are mainly gathered in two places: west of El-Hajeb and west of Ain Bittit (Fig. 10). The springs around Ain Bittit are located in the area where the topographic transition between the TMA and plain is smooth compared to other places. This area is also characterized by recent deposits of travertine that are absent in other places on the northern border of the TMA (Ennadifi, 1975). The superposition of the springs on the fracturing map reveals that they are clearly located in the continuation of the NW-SE features of the TMA, and not in the continuation of the NE-SW 
features. This result is in agreement with the interpretation of Qarqori et al. (2012), who proposed that NW-SE fractures are the main water drains.

The TMA is mainly composed of Liassic karst affected by NE-SW fault-driven corridors and NW-SE widespread features. The two features affect the Mesozoic units at depth and could be drains for the circulation of water. These drains can favour both rainfall percolations at depth, because their sub-vertical dip, and lateral water connectivity at depth. This work points out that the NW-SE structures drive the lateral connectivity at depth and favour karst development by increasing the carbonate dissolution generating the karstic caves. Two hypotheses are proposed to explain the low connectivity of the NE-SW features: 1) they either juxtapose blocks with contrasted porosity, or 2) they are sealed with clay coming from the Miocene shales. Amraoui (2005) and Belhassan (2011) conducted a detailed analysis of the hydrology of the deep aquifer both in the TMA and the plain. Based on a large piezometer dataset, these authors built a map of the depth of the water table and deduced a northward flow of the water (Fig. 10). They proposed flow lines for which the trends are perfectly compatible with the water circulations along the NW-SE features both in the TMA and the plain of Saïss.

Figure 11 illustrates a model of water circulation from the TMA to the Neogene basin of Fes-Meknes taking into account both the previously described hydrological data and the new structural pattern stemming from this work. The precipitation occurring on the elevated relief of the TMA percolate into the Liassic dolomites across a fracture drain. A Triassic clay layer above the unconformity with the basement confines the circulation into the carbonate layers. The northward general dip of the stratigraphic layers of the TMA drives a northward migration of the water confined in the carbonate layers. The northern margin of the TMA is formed by a set of blocks of Mesozoic units limited by faults (Chalouan et al., 2014). These blocks collapse toward the deepest parts of the basin. The vertical throw along the normal faults is low enough to not disconnect the water paths to the basin. In addition to this regional pattern, the drainage is driven by NW-SE fractures that constitute a widespread network both in the TMA and in the basin. The combination of the regional faults trending NE-SW and the NW-SE fracture set generates a complex pattern of blocks that are more or less disconnected depending on the fault throws.

\section{6- Conclusions}

This study proposes a model of structural relationships between the Saïss basin and Tabular Middle Atlas. It points out the efficiency of combining an analysis using both SPOT images and DEM to propose a structural map. Two fault sets were extracted: a well-known one trending NE-SW and a new one oriented NWSE, both affecting the TMA and the basin. The NE-SW structures correspond to faulted corridors in the TMA and tiny flexures in the basin, initiated during a NW-SE extension occurring in the Late Miocene and corresponding to reactivated Liassic faults. The NW-SE structures correspond to a diffuse and ubiquitous deformation that affected the whole study area. This direction of deformation is clearly visible on satellite images after processing on the slope map of the MNT, while it was somewhat identified in previous studies on the region. These fracture sets control the dissolution of carbonates in the TMA forming the karst network and the development of the drainage pattern in the plain. We examined the consequences of this structural pattern in terms of hydrology, especially for the water connectivity between the TMA and the basin. A comparison with 
335 hydrological data reveals that these NW-SE features constitute the main connectivity for the deep-water circulations from the TMA to the basin. At least, we propose that water pathways are connected via diffuse

337 fracture porosity rather than by a localized drainage system. This study highlights the fact that a study combining

338 classical structural methods and hydrological data may significantly constrain the hydrology of an area.

340 Acknowledgments:

341 The work is part of the IRD program CORUS II that was funded by the Foreign Office of the French 342 government. The Spot images were acquired using the ISIS program supported by CNES, SPOT Image and 343 IGN. The cooperation program CNRS France/CNR Morocco funded the field trips. We thank the two reviewers 344 and the editor whose comments improved the initial manuscript. 
Figure Captions.

Figure 1: Location of the study area. a) Location map with the topography of northern Morocco, b) 3D view of the study area using Google Earth (image data: Google, DigitalGlobe) with the main morpho-structural units (red lines), c) N-S geological cross-section showing the different units.

Figure 2: Simplified geological map of the study area modified from a geological map (Ennadifi, 1975 and Amraoui 2005).

Figure 3: Map of the study area with the data used in this study. The red squares identify the SPOT images with the index number in the red tag. The relief map in the background is taken from the SRTM database with a pixel size of $90 \mathrm{~m}$.

Figure 4: Mosaic of the SPOT images used in this study. Table 1 summarizes the main characteristics.

Figure 5: Extraction of the contours based on the convolution techniques carried out using a diagonal matrix (Sobel filters). To better illustrate the processing, we only display two zooms of the two Sobel processing operations. Upper image: zoom of the middle part of the Saïss plain showing a NE-SW lineament highlighted by a N-S diagonal matrix. Middle image: zoom of the NE-SW lineaments of the TMA extracted with a NW-SE diagonal matrix.

Figure 6: Shaded images of the topography: a) light coming from the north, b) light coming from the east.

Figure 7: Distribution of the slopes at different scales. The adjusted plane was calculated in window of varying sizes (grey grid): a- $2.5 \times 2.5 \mathrm{~km}, \mathrm{~b}-7.5 \times 7.5 \mathrm{~km}$. The red lines indicate the trend and the relative value of the slope. On the left side, we plot: i) the polar diagrams of the azimuth versus the plunge of the slope and ii) the rose diagrams of the slope directions (in red) and river orientations (in blue).

Figure 8: Topographic surface network. The ridges in yellow and the channels in blue were extracted from the DEM with the Landserf software using a method developed by Wood (2000) and Schneider and Wood (2004). This processing technique well illustrates the contrasted topography between the plain and the TMA. It can be used to distinguish between several domains in the plain with different ridge and channel networks.

Figure 9: Structural map of the detected features on the right with a shaded relief as the background. In the left column, a half rose diagram of the fault orientation. The lower diagram in the left column displays the length distribution of the features.

Figure 10: Water pathways and fractures in the study area. The contour of the water table and the theoretical water flows are taken from Amraoui (2005) and Belhassan (2011). The deep water circulates toward the northwest. The flow direction fits with the NW-SE features both in the TMA and in the Saïss basin. The spring locations come from the geological map and from Amraoui (2005) and Belhassan (2011). 
Figure 11: Schematic section of the TMA and Saïss plain showing the inferred hydrological relationships between the three aquifers: the karst of the TMA, the superficial free aquifer and the deep confined aquifer of the plain. The water circulation coming from the karst of the TMA is driven both by regional faults trending NE-SW and by a widespread fracture trending NW-SE. The two structural sets generate a complex pattern inside the basin making it difficult to implement the drilling.

384

385 Table 1 Main characteristics of the SPOT images.

\begin{tabular}{|c|c|c|c|c|c|c|c|c|}
\hline Scene & SPOT & $\begin{array}{l}\text { upper left } \\
\text { corner }\end{array}$ & $\begin{array}{c}\text { upper right } \\
\text { corner }\end{array}$ & $\begin{array}{c}\text { lower left } \\
\text { corner }\end{array}$ & $\begin{array}{c}\text { lower right } \\
\text { corner }\end{array}$ & $\begin{array}{l}\text { Image } \\
\text { type }\end{array}$ & $\begin{array}{c}\text { Pixel } \\
\text { size }\end{array}$ & Date \\
\hline 0161003-2 & 5 & $\begin{array}{l}\mathrm{N} 34^{\circ} 1^{\prime} 49^{\prime \prime} \\
\mathrm{W} 4^{\circ} 57^{\prime} 41^{\prime \prime}\end{array}$ & $\begin{array}{c}\text { N3353'34" } \\
\text { W419'18" } 3\end{array}$ & $\begin{array}{l}\mathrm{N}^{\circ} 3^{\circ} 22^{\prime} 3^{\prime \prime} \\
\mathrm{W} 4^{\circ} 29^{\prime} 7\end{array}$ & $\begin{array}{c}\text { N3330'16" } \\
\text { W5 }{ }^{\circ} 7^{\prime} 17^{\prime \prime}\end{array}$ & PAN & $5 \mathrm{~m}$ & $2006-10-14$ \\
\hline 0161003-1 & 2 & $\begin{array}{l}\text { N033 } 57^{\circ} 32^{\prime \prime} \\
\text { W0054' } 14^{\prime \prime}\end{array}$ & $\begin{array}{l}\text { N03351'31" } \\
\text { W00504'05" }\end{array}$ & $\begin{array}{l}\text { N03325'56" } \\
\text { W00551'31" }\end{array}$ & $\begin{array}{l}\text { N03319'57" } \\
\text { W005¹3'36" }\end{array}$ & XS & $20 \mathrm{~m}$ & $2007-10-21$ \\
\hline 0161003-3 & 5 & 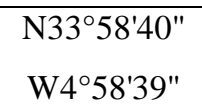 & $\begin{array}{l}\text { N3350'25" } \\
\text { W4 } 20^{\prime} 17^{\prime \prime}\end{array}$ & $\begin{array}{c}\text { N33ํ18'53" } \\
\text { W430'6" }\end{array}$ & $\begin{array}{l}\text { N33 } 27^{\circ} 6^{\prime \prime} \\
\text { W5 } 5^{\circ} 14^{\prime \prime}\end{array}$ & PAN & $5 \mathrm{~m}$ & 2006-10-14 \\
\hline 0161003-4 & 4 & $\begin{array}{l}\text { N03351'02" } \\
\text { W005¹7'04" }\end{array}$ & $\begin{array}{l}\text { N0334'ㄹ' } \\
\text { W00438'24" }\end{array}$ & $\begin{array}{l}\text { N03319'22" } \\
\text { W00525'49" }\end{array}$ & $\begin{array}{l}\text { N03313'45" } \\
\text { W0044'ㄱ' }\end{array}$ & XI & $20 \mathrm{~m}$ & $2007-02-28$ \\
\hline 0189121-1 & 4 & $\begin{array}{l}\text { N03400'46" } \\
\text { W0054' } 22^{\circ}\end{array}$ & $\begin{array}{l}\text { N0335'46" } \\
\text { W00507'15" }\end{array}$ & $\begin{array}{l}\text { N03329'10" } \\
\text { W005 } 54^{\prime} 38^{\prime \prime}\end{array}$ & $\begin{array}{l}\mathrm{N}^{0} 33^{\circ} 23^{\prime} 12^{\prime \prime} \\
\text { W00516'45" }\end{array}$ & XI & $20 \mathrm{~m}$ & 2006-01-18 \\
\hline 0157076-1 & 5 & $\begin{array}{l}\text { N34 } 34^{\prime} 13 " \\
\text { W5 } 21^{\prime} 30^{\prime \prime}\end{array}$ & 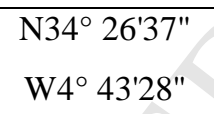 & $\begin{array}{l}\mathrm{N} 33^{\circ} 55^{\prime \prime} \\
\mathrm{W} 4^{\circ} 52^{\prime} 48^{\prime \prime}\end{array}$ & $\begin{array}{l}\text { N34 } 2^{\prime} 36^{\prime \prime} \\
\text { W5 } 30^{\prime} 36^{\prime \prime}\end{array}$ & PAN & $5 \mathrm{~m}$ & $2006-11-30$ \\
\hline 0157076-2 & 5 & $\begin{array}{l}\text { N33 } 44^{\prime} 34^{\prime \prime} \\
\text { W5 } 36^{\prime} 17^{\prime \prime}\end{array}$ & $\begin{array}{l}\mathrm{N}^{\prime} 33^{\circ} 36^{\prime} 59^{\prime \prime} \\
\mathrm{W} 4^{\circ} 58^{\prime} 37^{\prime \prime}\end{array}$ & $\begin{array}{l}\text { N33 } 5^{\prime} 23^{\prime \prime} \\
\text { W5 }{ }^{\circ} 7^{\prime} 48^{\prime \prime}\end{array}$ & $\begin{array}{l}\mathrm{N}^{\prime} 3^{\circ} 12^{\prime} 56^{\prime \prime} \\
\mathrm{W} 5^{\circ} 45^{\prime} 16^{\prime \prime}\end{array}$ & $\mathrm{HI}$ & $10 \mathrm{~m}$ & $2006-11-30$ \\
\hline
\end{tabular}


References:

Aït Brahim, L., Chotin, P., Hinajc, S., Abdelouafia, A., El Adraouia, Nakcha, C., Dhont, D., Charroud, M., Sossey Alaoui, F., Amrhar, M., Bouaza, A., Tabyaoui, H., Chaouni, A. 2002. Paleostress evolution in the Moroccan African margin from Triassic to Present. Tectonophysics 357, 187-205.

Amraoui, F., Razack, M., Bouchaou, L., 2004. Comportement d'une source karstique soumise à une sécheresse prolongée : la source Bittit (Maroc). C. R. Geoscience. 336, 1099-1109.

Amraoui, F. 2005. Contribution à la connaissance des aquifères kartiques : cas du Lias de la plaine de Saïs et du Causse moyen atlasique tabulaire (Maroc), Faculté des Sciences. Université Hassan II Ain Chock,

Arboleya, M.L., Teixell, A., Charroud, M., Julivert, M., 2004. A structural transect through the High and Middle Atlas of Morocco. Journal of African Earth Sciences. 39, 319-327.

Bachiri Taoufiq, N., Barhoun, N., Suc, J.-P., 2008. Les environnements continentaux du corridor rifain (Maroc) au Miocène supérieur d'après la palynologie. Geodiversitas. 30, 41-58.

Barbero, L., Jabaloy, A., Gómez-Ortiz, D., Pérez-Peña, J.V., Rodríguez-Peces, M.J., Tejero, R., Estupiñán, J., Azdimousa, A., Vázquez, M., Asebriy, L., 2011. Evidence for surface uplift of the Atlas Mountains and the surrounding peripheral plateaux: Combining apatite fission-track results and geomorphic indicators in the

Barcos, L., Jabaloy, A., Azdimousa, A., Asebriy, L., Gómez-Ortiz, D., Rodríguez-Peces, M.J., Tejero, R., PérezPeña, J.V. 2014. Study of relief changes related to active doming in the eastern Moroccan Rif (Morocco)

Bargach, K., Ruano, P., Chabli, A., Galindo-Zaldivar, J., Chalouan, A., Jabaloy, A., Akil, M., Ahmamou M., using geomorphological indices, Journal of African Earth Sciences, 100, 493-509,

Belhassan, K., 2011. Hydro-Geological Context of Groundwater Mikkes and Different Variations of its Springs Flows (Morocco). Research Journal of Earth Sciences. 3, 15-26.

Bentayeb, A., Leclerc, C., 1977. Le Causse moyen- atlasique, in: Editions du Service Géologique du Maroc (Ed.), Ressources en Eau du Maroc, 37-84. 
Benmakhlouf, M., Riguzzi, F. 2014. Active faulting in the frontal Rif Cordillera (Fes region, Morocco): Constraints from GPS data, Journal of Geodynamics, 77, 110-122.

Chamayou, J., Combe, M., Genetier, B., Leclerc, C., 1975. Le bassin de Meknès-Fè , in: Maroc, E.d.S.G.o.d. (Ed.), Ressources en Eau du Maroc. 41-71.

Charroud, M., Cherai, B., Benabdelhadi, M., Falgere, C., 2007. Impact de la néotectonique Quaternaire sur la dynamique sédimentaire du Saïs (Maroc) : du bassin d'avant fosse Pliocène au plateau continental Quaternaire. Quaternaire. 18, 327-334.

Dauteuil, O.,1995. Fault pattern from Seabeam processing: the Western part of the Blanco fracture Zone (NE Pacific). Mar. Geophys. Res. 17/1,17-35.

Ennadifi, M.Y., 1975. Carte Géologique du Maroc au 1/100000, 1975, Service Géologie du Maroc, Rabat.

Essahlaoui, A., Sahbi, H., El-Yamine, N., 2002. Application de la géophysique (method géoélectrique) à la reconnaissance du plateau de Meknès. Geologica Belgica, 2000, 35-53

Essahlaoui, A., El Ouali, A., 2003. Détermination de la structure géologique de la partie Sud de la plaine du Saiss (bassin de Meknes-Fes, Maroc) par la méthode géoélectrique. Bulletin of Engineering Geology and

Essahlaoui, A., Sahbi, H., e, B.L., El-Yamine, N., 2001. Reconnaissance de la structure géologique du bassin de Saïss occidental, Maroc, par sondages electriques. Journal of African Earth Sciences. 32 , 777-789.

Fassi, D., 1999. Les formations superficielles du Sais de Fès et de Méknès. Notes et mémoires du service géologique. 389, pp. 527

Frizon de Lamotte, D., Leturmy, P., Missenard, Y., Khomsi, S., Ruiz, G., Saddiqi, O., Guillocheau, F., Michard, A., 2009. Mesozoic and Cenozoic vertical movements in the Atlas system (Algeria, Morocco, Tunisia): An overview. Tectonophysics. 475, 9-28.

Harmouzi, O., 2010. Reconnaissance détaillée de la partie nord-est du Bassin de Saïss (MAROC): interprétation de sondages électriques verticaux par combinaison des méthodes statistique, géostatistique et d'inversion, February 242004 Al Hoceima earthquake. European-Mediterranean Seismic Centre Newsletter. 21, 7-10. 
Perrin, J.L., Raïs, N., Chahinian, N., Moulin, P., Ijjaali, M. 2014. Water quality assessment of highly polluted rivers in a semi-arid Mediterranean zone Oued Fez and Sebou River (Morocco), Journal of Hydrology, 510, 26-34,

Piqué, A., Tricart, P., Guiraud, R., Laville, E., Bouaziz, S., Amrhar, M., Aït Ouali, R., 2002. The MesozoicCenozoic Atlas belt (North Africa): an overview. Geodinamica Acta. 15, 85-208.

Qarqori, K., Rouai, M., Moreau, F., Saracco, G., Dauteuil, Hermitte, D., Boualoul, M., Le Carlier de Veslud, C., 2012. Geo-electrical tomography investigating and modeling of fractures network around Bittit spring (Middle Atlas, Morocco). International Journal of Geophysics. Pp. 13

Vergés, J., Manel Fernàndez, M. 2012. Tethys-Atlantic interaction along the Iberia-Africa plate boundary: The Betic-Rif orogenic system Tectonophysics 579, 144-172

Wood, J. (2013) LandSerf 2.3, http://www.landserf.org

Zarhloule, Y., Lahrache, A., Ben Abidate, L., Khattach, D., Bour, S., Boukdir, A., Ben Dhia, H., 2001. La prospection geothermique de surface au Maroc: hydrodynamisme, anomalies thermiques et indices de surface. Journal of African Earth Sciences. 32, 851-867.

Zizi M. (2002) Triassic-Jurassic extrensional systems and their Neogene reactivation in northern morocco: the rides Prerifaines and Guercif basin. Notes et mémoires du service géologique marocain, 416. 


\section{ACCEPTED MANUSCRIPT}

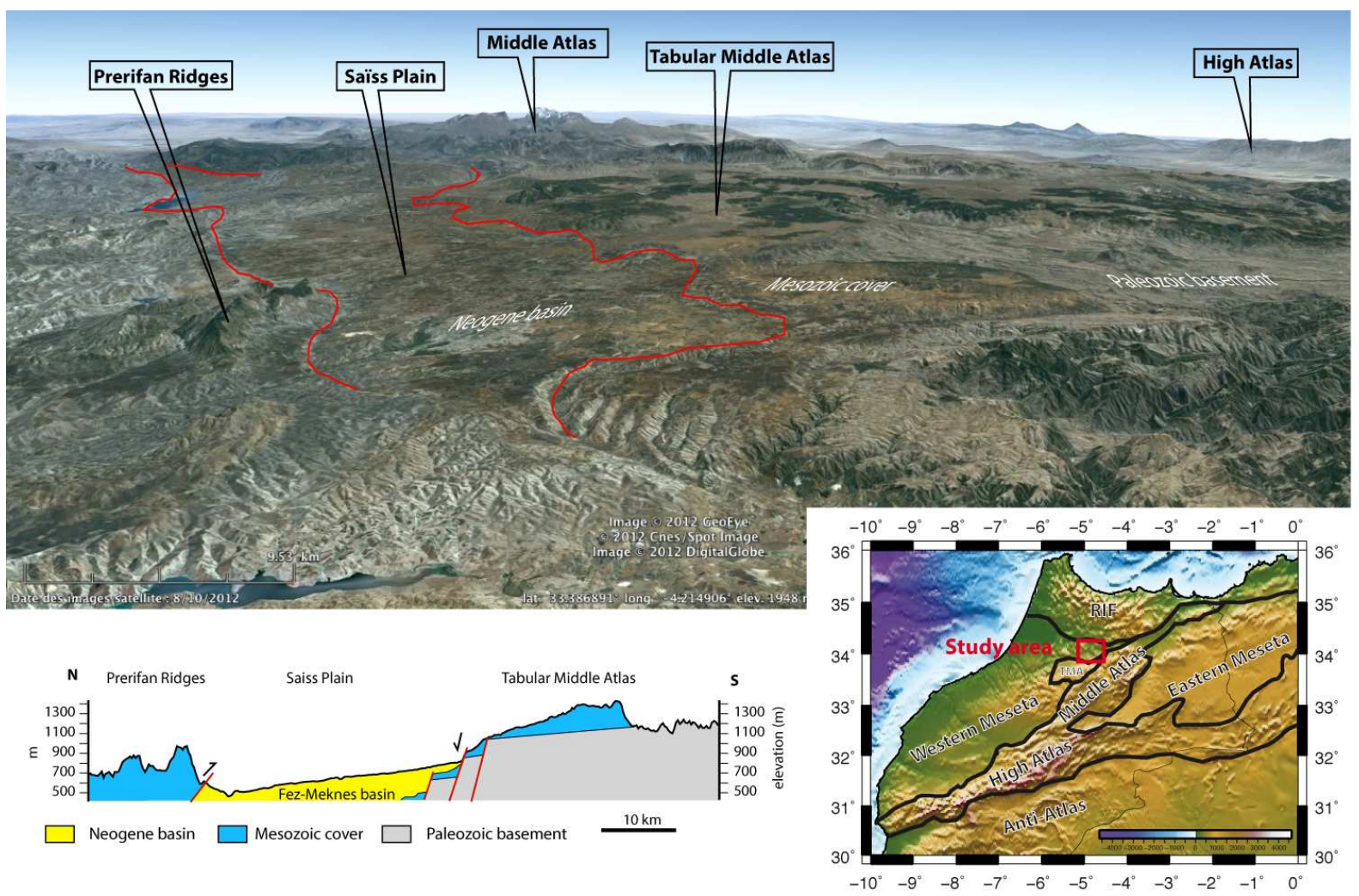

Figure 1 


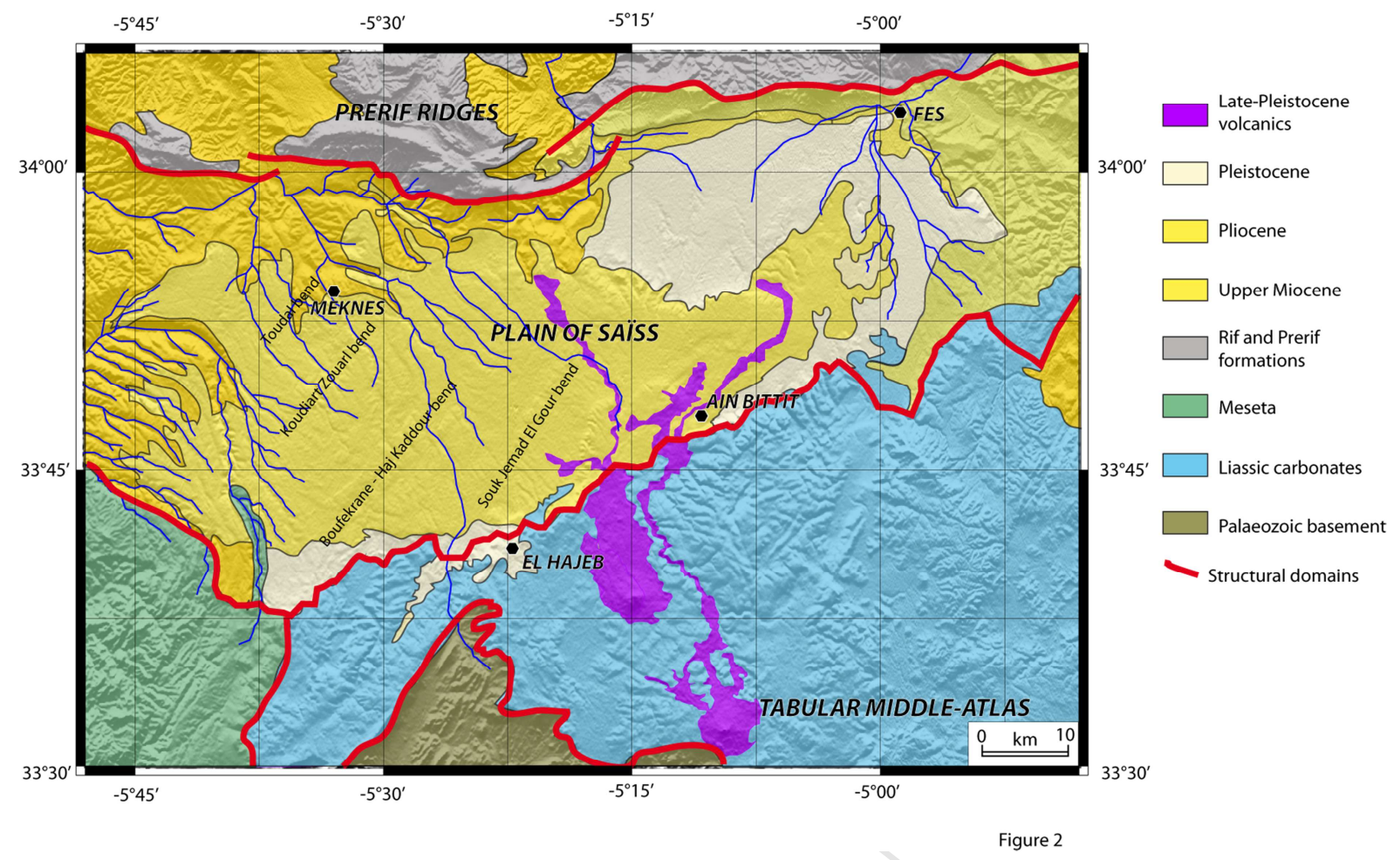




\section{ACCEPTED MANUSCRIPT}

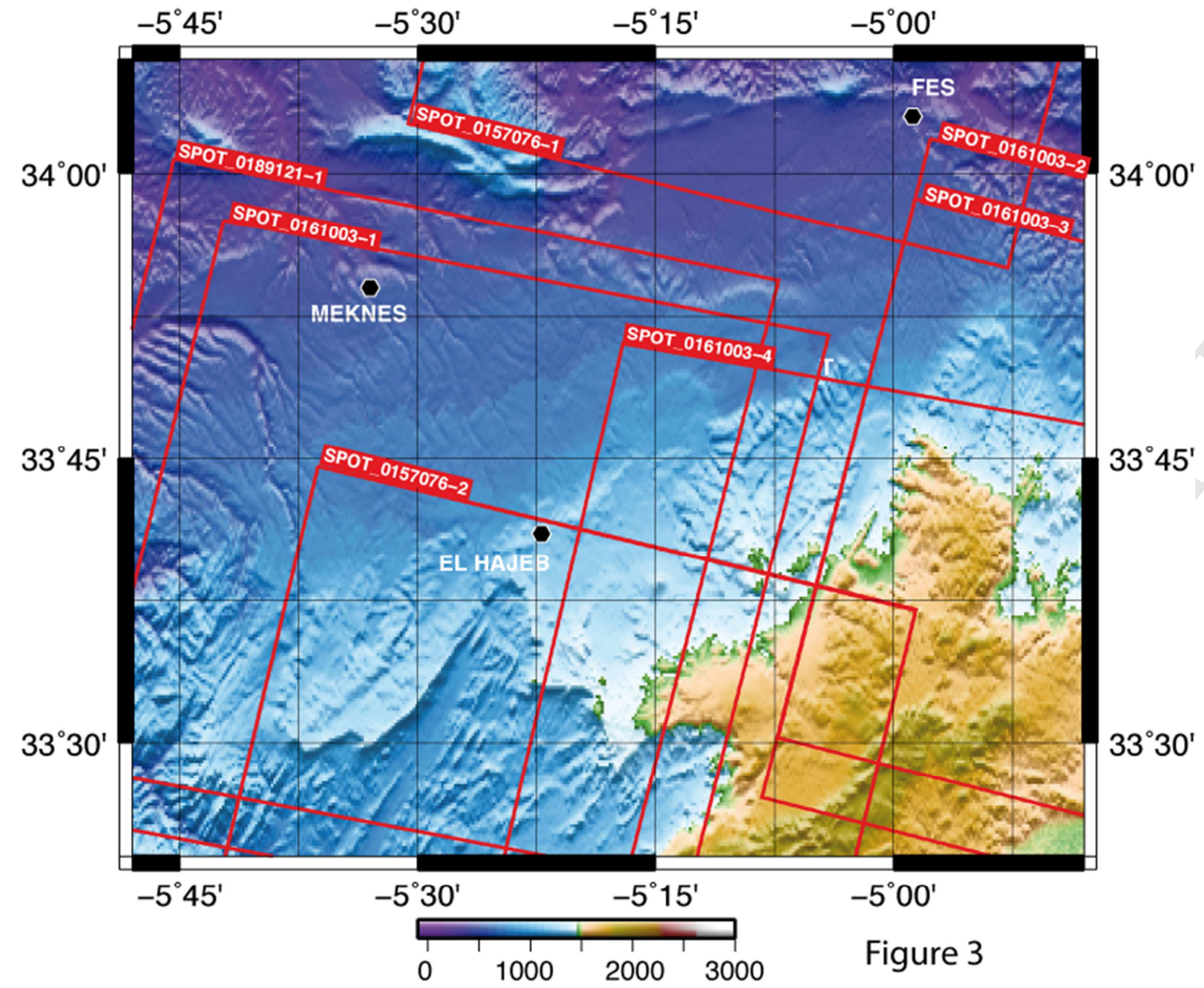




\section{ACCEPTED MANUSCRIPT}

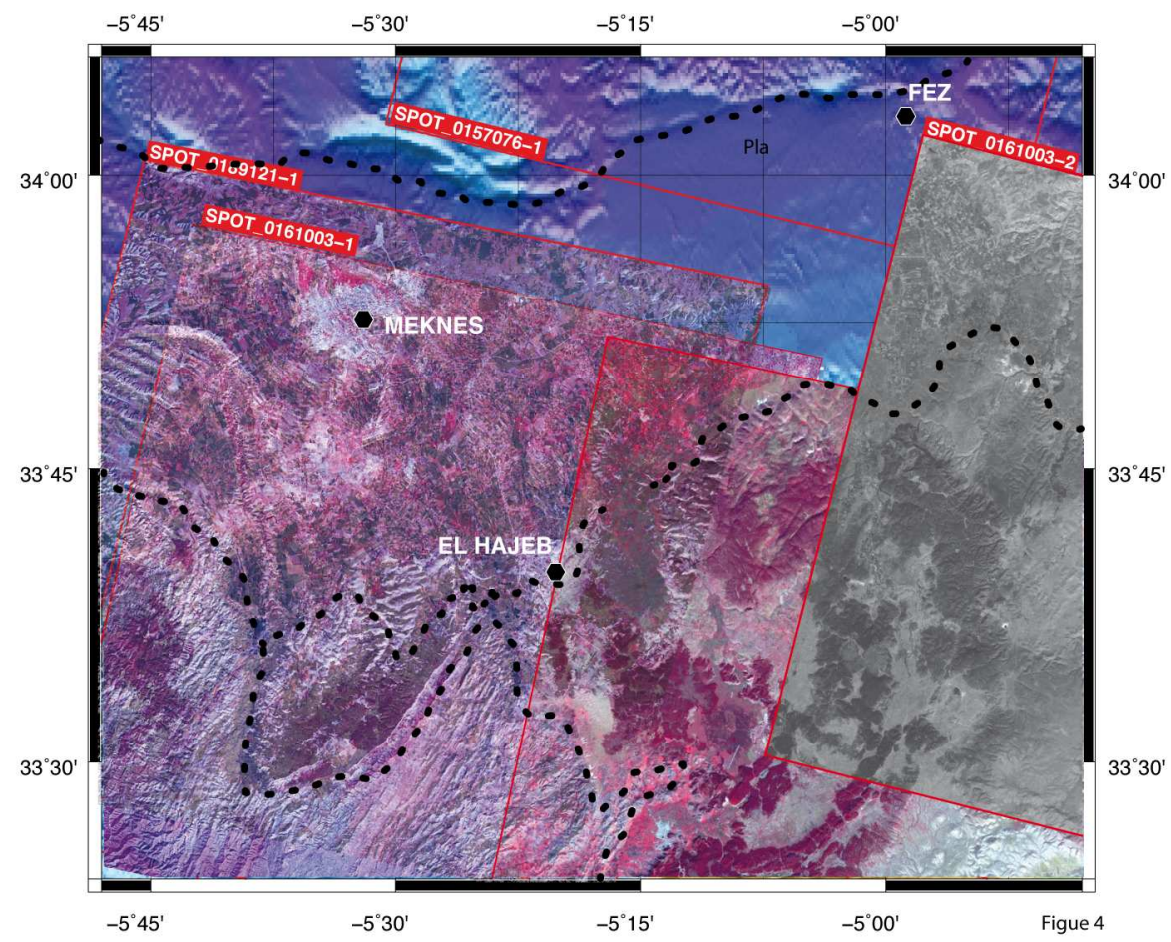


$\mathrm{N}-\mathrm{S}$ convolution matrix ( $5 \times 5$ pixels)

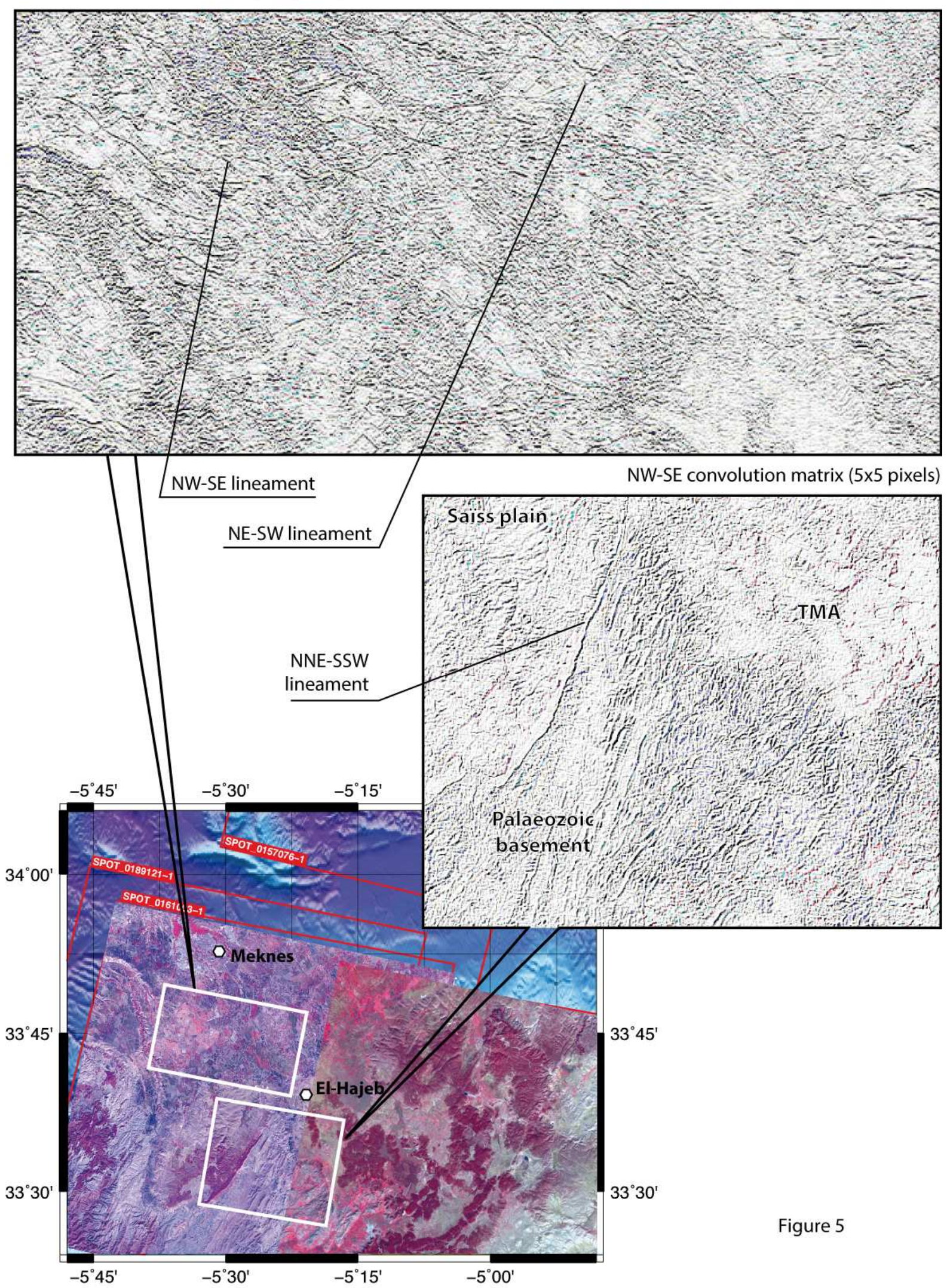




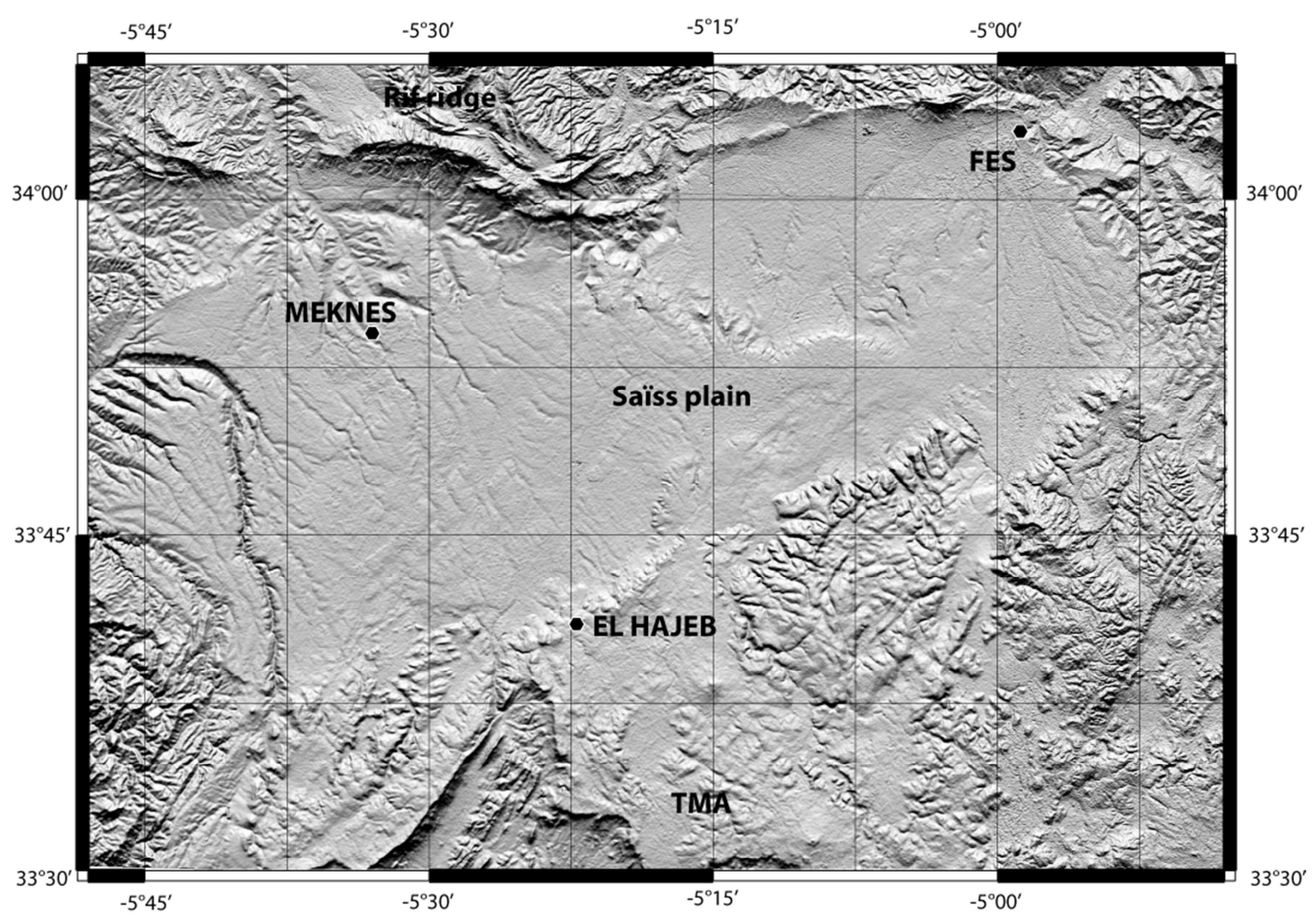

$-5^{\circ} 45^{\prime}$

$-5^{\circ} 30^{\prime}$

$-5^{\circ} 15^{\prime}$

$-5^{\circ} 00^{\prime}$

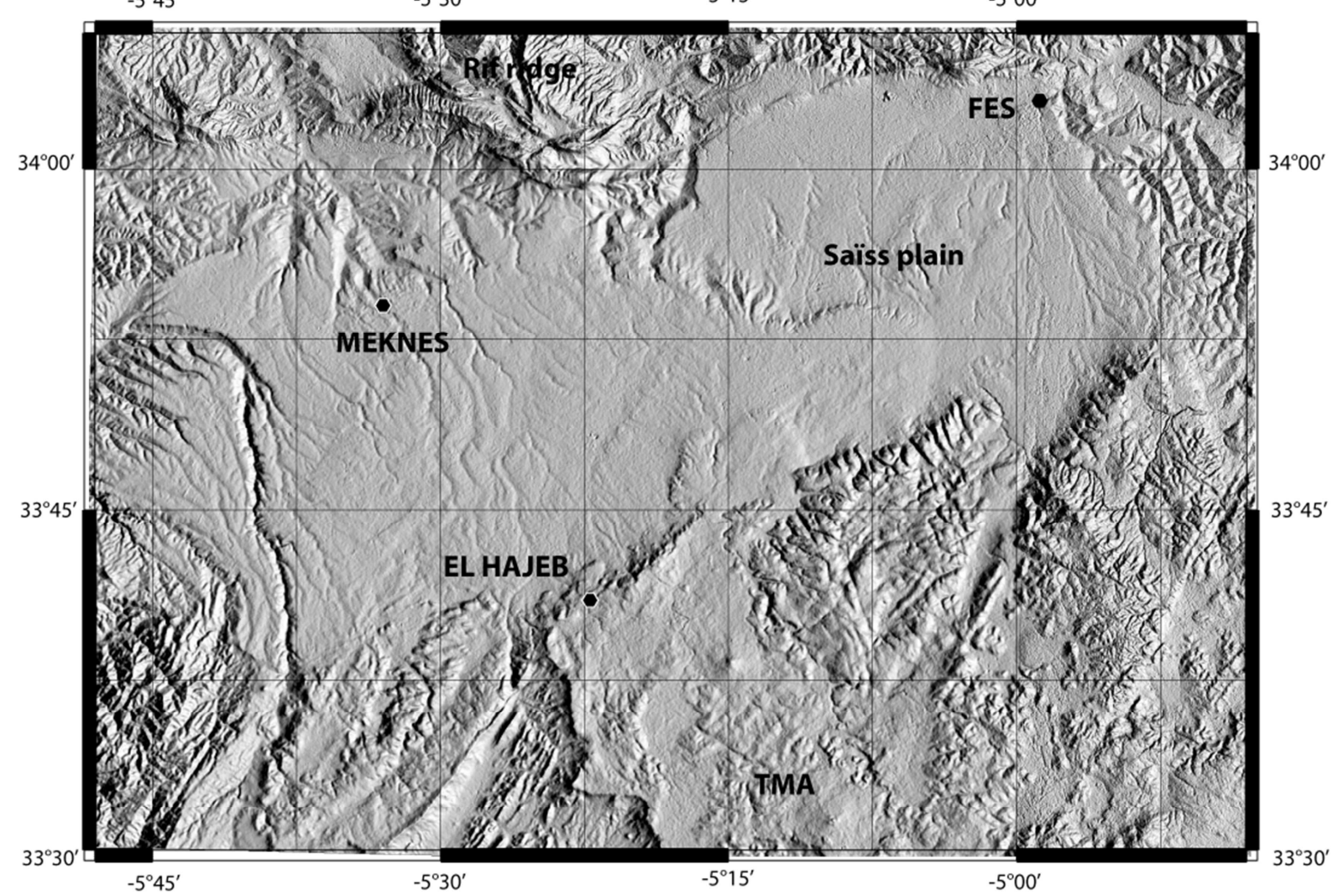

Figure 6 


\section{ACCEPTED MANUSCRIPT}

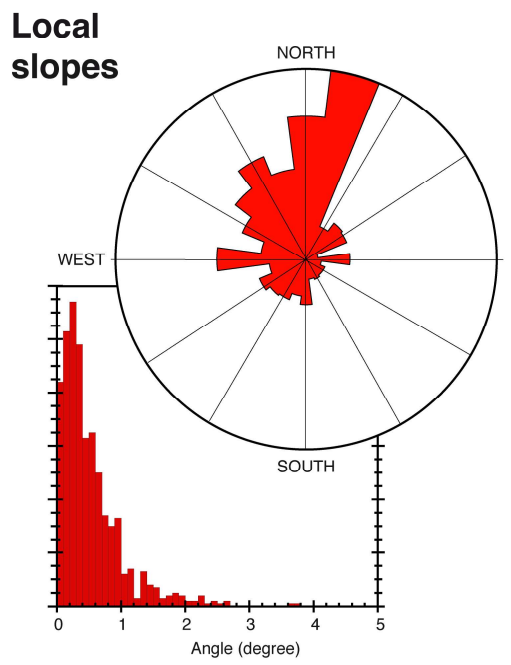

window 2.5 x $2.5 \mathrm{~km}$
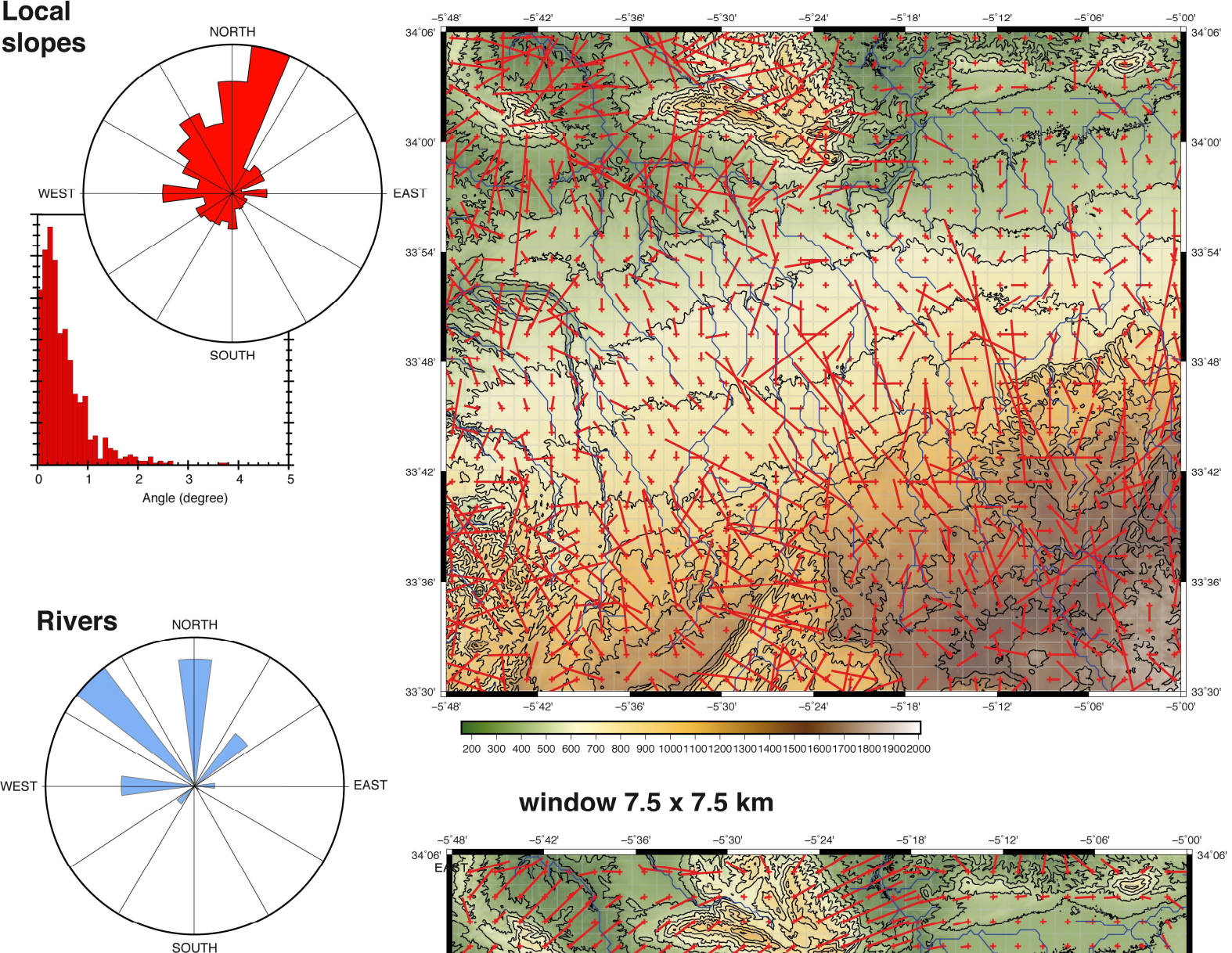

window 7.5 x 7.5 km
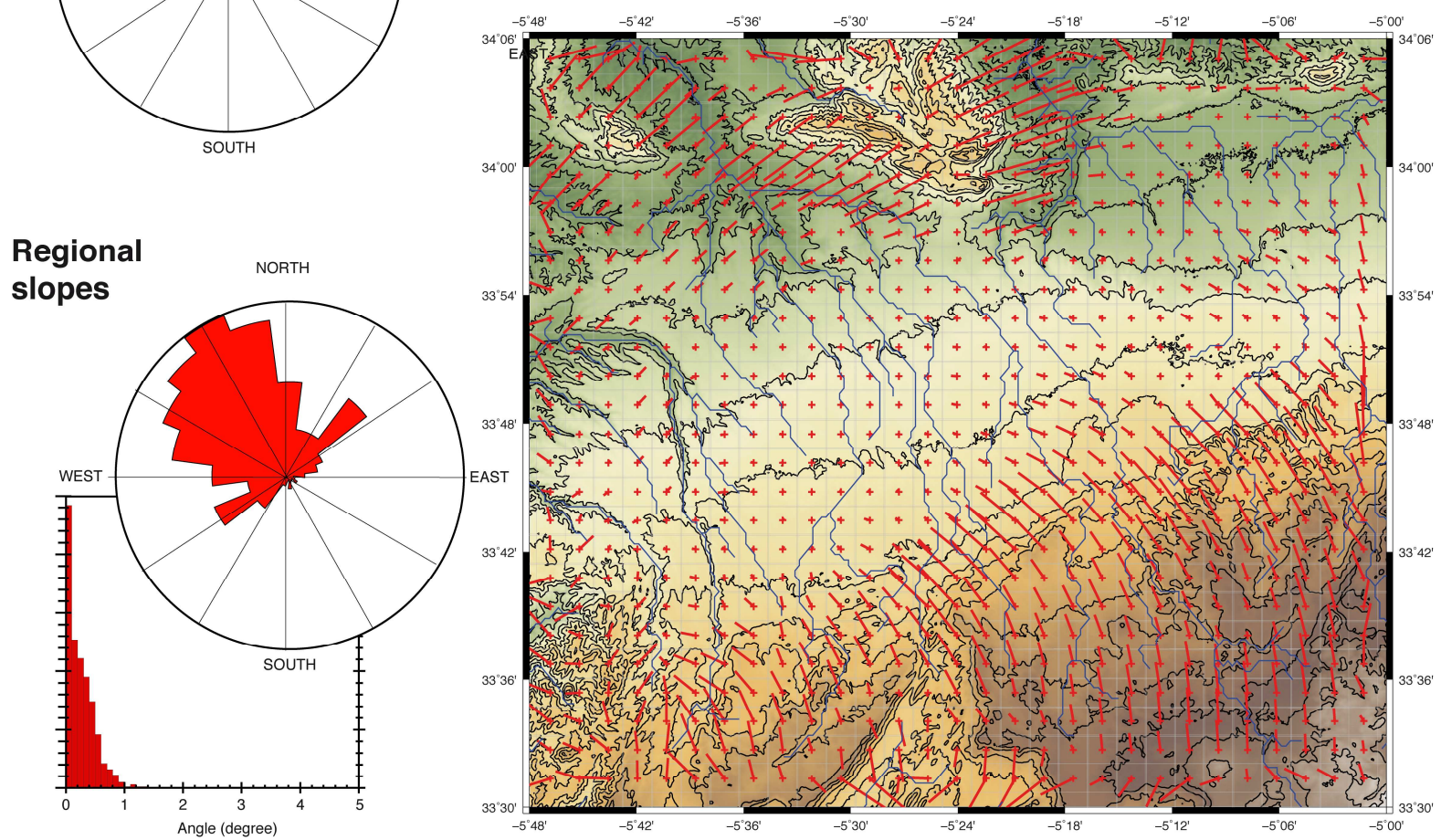

wh

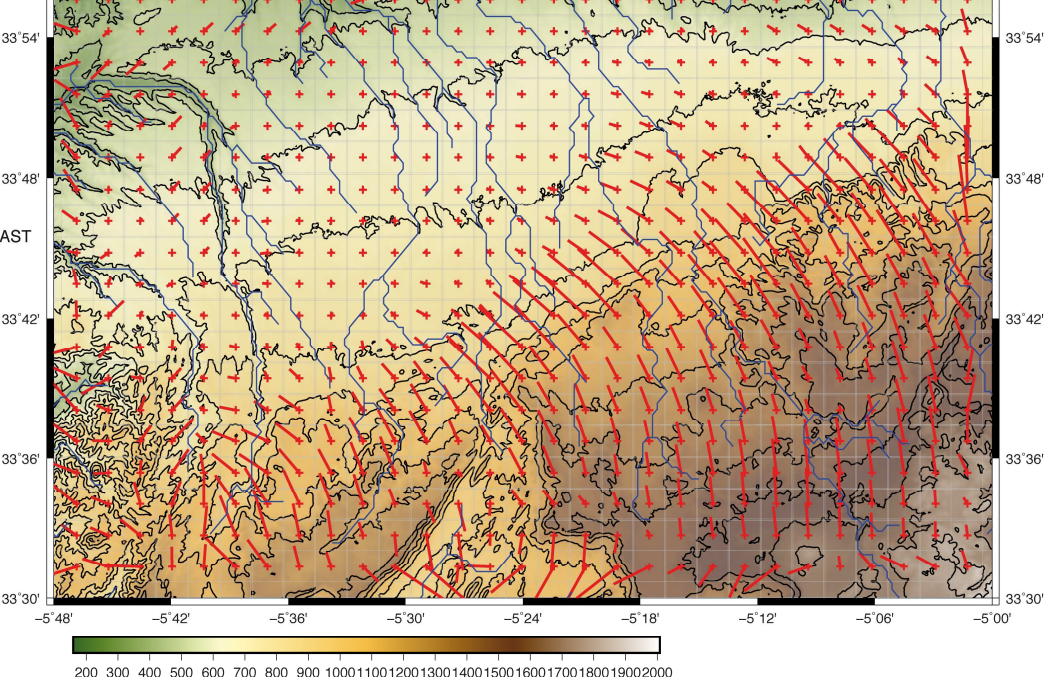




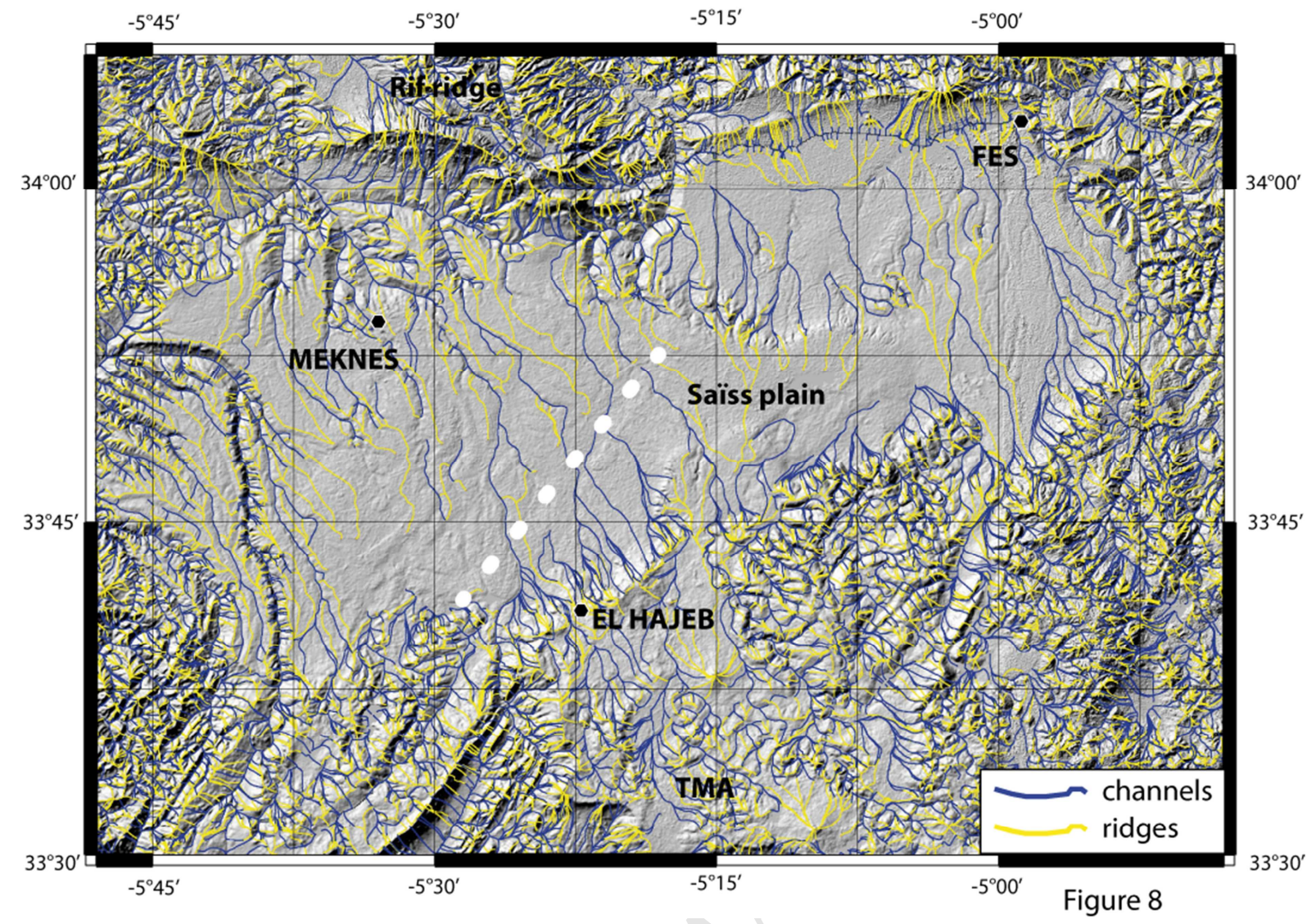




\section{ACCEPTED MANUSCRIPT}
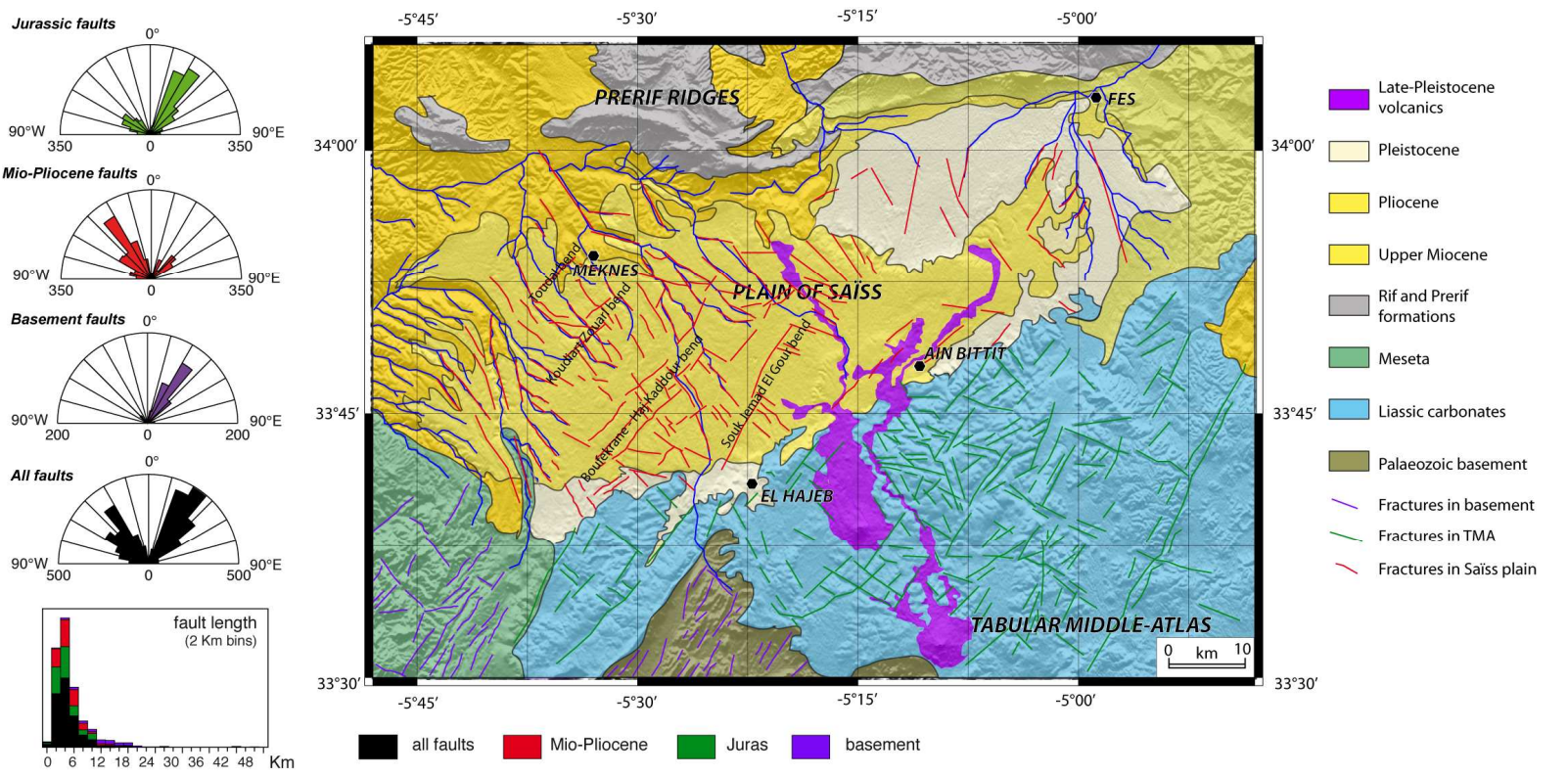

Figure 9 


\section{ACCEPTED MANUSCRIPT}

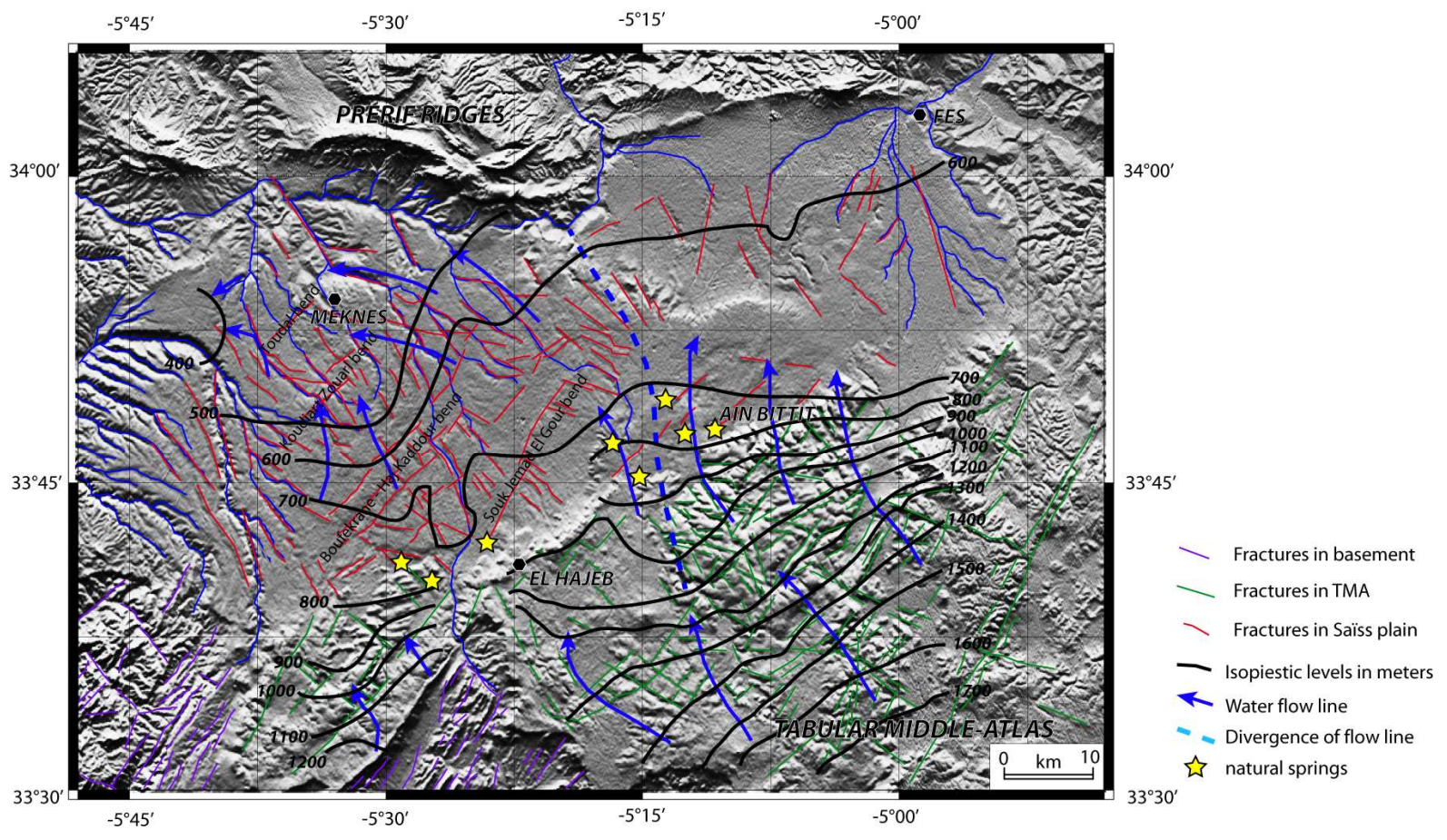

Figure 10 


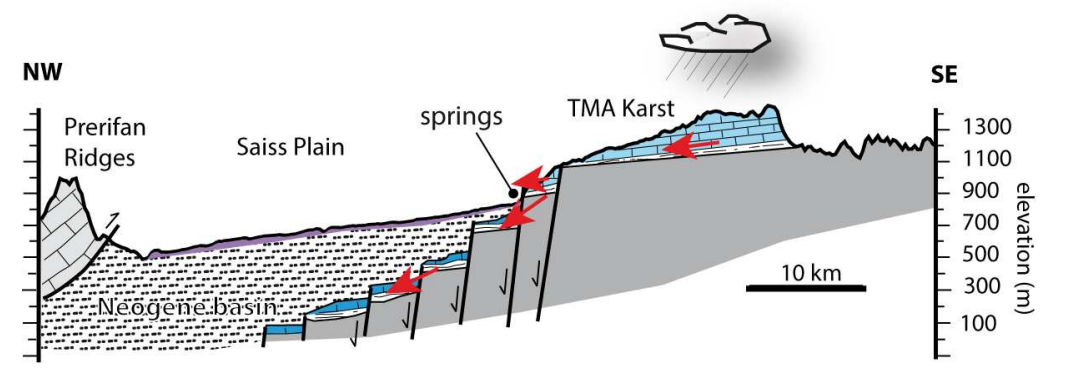

\section{GEOLOGICAL SETTINGS}

$\because \begin{aligned} & \text { Neogene } \\ & \text { basin }\end{aligned}$

Mesozoic

$-\rightarrow$ Mesozoic

shales

Paleozoic

HYDROGEOLOGICAL SETTINGS

$\square$ superficial aquifer $\square$ confined aquifer $\square$ karstic aquifer

$\leftarrow$ water flows

figure 11 
Research Highlights:

- We mapped fracture pattern in Saïss basin and Middle-Atlas with SPOT images and DEM.

- We pointed out a new fracture set trending NW-SE in addition to famous NE-SW trend.

- The NE fractures control the water paths from the Middle-Atlas to the Saïss basin.

- We propose a model of water circulation from the TMA to the Saïss basin. 